\title{
A chromosome integrative vector system utilizing DNA fragments of a lysogenic phage of Rhizobium leguminosarum
}

\author{
Toshiki Uchiumi,* ShIRo HigaShi and Mikiko Abe \\ Department of Biology, Faculty of Science, Kagoshima University, Kagoshima 890, Japan
}

(Received 15 February 1993; revised 27 May 1993; accepted 7 June 1993)

\begin{abstract}
The attachment site (attP) of phage $\phi \mathrm{U}$, a lysogenic phage of Rhizobium leguminosarum biovar trifolii, was identified on a $6.0 \mathrm{~kb} E c o$ RI fragment of the phage DNA. Plasmid pCI6 was constructed by cloning this EcoRI fragment into the EcoRI site of suicide plasmid vector pSUP202. Escherichia coli S17-1 harbouring plasmid pCI6 was mated with wild-type $R$. leguminosarum biovar trifolii strain $4 S$ and its lysogenic strain $4 \mathrm{~S}(\phi \mathrm{U})$ using tetracycline resistance $\left(\mathrm{Tc}^{r}\right)$ as a selection marker. $T$ he $T c^{r} R$. leguminosarum biovar trifolii transconjugants appeared at high frequency $\left(10^{-3}-10^{-4}\right.$ per recipient cell in both matings). Southern hybridization with the attP fragment and pSUP202 as probes indicated that plasmid pCI6 integrated into the chromosome of all these transconjugants in the same manner as phage $\phi \mathrm{U}$.
\end{abstract}

\section{Introduction}

The lysogenic phages of Rhizobium have contributed to the analysis of Rhizobium genes (Kowalski, 1967; Buchanan-Wollaston, 1979; Sik et al., 1980; Finan et al., 1984; Martin \& Long, 1984). Phage 16-3, a lysogenic phage of Rhizobium meliloti, has been investigated in detail (Dorgai et al., 1981, 1986) and Hermesz et al. (1992) constructed cloning vectors using the attachment site (attP) of phage 16-3. These vectors integrated into the chromosome of $R$. meliloti by site specific recombination between the $a t t P$ site on the vectors and the $a t t B$ site on the host bacterial chromosome with simultaneous infection of specific helper phage. The integrated vectors were stably maintained in $R$. meliloti. This integrative vector system will play an important role in genetic studies of the Rhizobium-legume symbiosis, because loss of vectors and cloned genes during nodulation has been a problem (Long, 1989).

The integrative site-specific recombination of lysogenic bacteriophage is well understood in coliphage $\lambda$. Phage $\lambda$ integrates its genome into the host bacterial chromosome by recombination between specific phage (attP) and bacterial $(a t t B)$ sites. As a result of integration, two new DNA junctions, att $L$ and $a t t R$, are generated on the left and right borders of the prophage genome. If a lysogenic phage integrates into the chromosome of the host bacteria in the same manner as phage $\lambda$, three fragments of attP, attL and attR can be detected by Southern

*Author for correspondence. Fax +81992 85-8029. hybridization. Waldman et al. (1986) distinguished attL and att $R$ fragments among the restriction fragments prepared from the lysogenic Haemophilus influenzae strain, L-10. When total DNA of lysogenic strain L-10 digested with restriction endonuclease was hybridized with DNA of lysogenic phage HP1cl, attL and attR fragments were detected as new bands which did not exist in restriction fragments of vegetative phage DNA. The attP fragment was detected as a very faint band, presumably because the copy number of the vegetative phage DNA was very low in the lysogen. Duchrow \& Giffhorn (1987) also reported the detection of attL, att $R$ and attP fragments of a lysogenic strain of Rhodobacter sphaeroides and its lysogenic phage $\phi \mathrm{RsG1}$ in the same way.

Lysogenic phage $\phi \mathrm{U}$ has been shown to lysogenize Rhizobium leguminosarum biovar trifolii strain 4S (Uchiumi et al., 1989. Phage $\phi \mathrm{U}$ was designated phage U-mole in the report.). It was suggested that phage $\phi \mathbf{U}$ integrates its genomic DNA into the host chromosome during lysogeny, and that the attP site may locate on a $6.0 \mathrm{~kb} E c o \mathrm{RI}$ fragment of phage $\phi \mathrm{U}$ DNA (Uchiumi et al., 1989). The DNA fragments corresponding to att $L$ and $a t t R$ were thought to be the $7.4 \mathrm{~kb}$ and $5.0 \mathrm{~kb} E c o$ RI fragments also found in the lysogen. We hypothesized that if a plasmid carrying the attP fragment could be constructed and introduced into the host Rhizobium cell, the recombinant plasmid might integrate into the host chromosome by attP/attB-mediated site-specific recombination. Such a construct would be useful for future studies on Rhizobium genetics. We report here the 
construction of a suicide plasmid vector carrying the attP fragment of phage $\phi \mathrm{U}$ DNA and high frequency integration of this vector into the chromosome of $R$. leguminosarum biovar trifolii.

\section{Methods}

Phage, plasmids and bacterial strains. The relevant characteristics of the phage, plasmids and bacterial strains used in this study are shown in Table 1 . One of the symbiotically effective lysogenic strains, $R$. leguminosarum biovar trifolii $4 \mathrm{~S}(\phi \mathrm{U})$, was used in this study.

Media and antibiotics. E. coli strains were maintained and cultured in LB medium. Rhizobium strains were maintained on mannitol-yeast agar medium (Keele et al., 1969). TY medium (Beringer, 1974) was used for DNA preparation, phage $\phi \mathrm{U}$ induction and mating. For selection of transconjugants from $E$. coli and Rhizobium mating mixtures, Sherwood's minimal agar plates (Sherwood, 1970) were employed. Antibiotics were used at the following concentrations: tetracycline (Tc) $20 \mu \mathrm{g} \mathrm{ml}^{-1}$; chloramphenicol (Cm) $30 \mu \mathrm{g} \mathrm{ml}^{-1}$; ampicillin (Ap) $50 \mu \mathrm{g} \mathrm{ml}^{-1}$; and mitomycin $\mathrm{C}$ for phage induction, $0 \cdot 1 \mu \mathrm{g} \mathrm{ml}^{-1}$.

Isolation of DNA and restriction endonuclease digestion. Plasmid isolation from $E$. coli was done on a small scale according to Birnboim \& Doly (1979), for routine analysis. For cloning vector and template for hybridization probes, the plasmid was purified according to Hattori et al. (1985). Isolation of phage $\phi U$ DNA was performed as described by Yamamoto et al. (1970) and Dallmann et al. (1979). Total cellular DNA from Rhizobium was prepared by the method of Casse $e t$ al. (1979) as modified by Higashi et al. (1983). Isolated DNAs were digested with appropriate restriction endonucleases according to standard methods.

Table 1. Bacterial strains, phage and plasmids

\begin{tabular}{|c|c|c|}
\hline & Relevant characteristics* & Reference or source \\
\hline \multicolumn{3}{|c|}{ Rhizobium strains } \\
\hline $4 \mathrm{~S}$ & Wild-type & $\begin{array}{l}\text { Higashi \& Abe } \\
(1980)\end{array}$ \\
\hline $4 \mathrm{~S}(\phi \mathrm{U})$ & Lysogen of strain $4 \mathrm{~S}$ & Uchiumi et al. (1989) \\
\hline CII01 & Transconjugant, $\mathrm{Tc}^{\mathrm{r}}$ & This work \\
\hline CI301 & Transconjugant, $\mathrm{Tc}^{\mathrm{r}}$ & This work \\
\hline \multicolumn{3}{|l|}{ E. coli strains } \\
\hline S17-1 & tra gene on chromosome & Simon et al. (1982) \\
\hline S17-1(pCI6) & S17-1 harbouring pCI6 & This work \\
\hline JM109 & Cloning host for pUC18 & $\begin{array}{l}\text { Yanisch-Perron et } \\
\text { al. (1985) }\end{array}$ \\
\hline LE392 & Cloning host & $\begin{array}{l}\text { Sambrook et al. } \\
\text { (1989) }\end{array}$ \\
\hline VCS 257 & Cloning host & Stratagene \\
\hline \multicolumn{3}{|l|}{ Phage } \\
\hline$\phi \mathrm{U}$ & $\begin{array}{l}\text { Lysogenic phage of } \\
\text { Rhizobium }\end{array}$ & Uchiumi et al. (1989) \\
\hline \multicolumn{3}{|l|}{ Plasmids } \\
\hline pSUP202 & $m o b^{+} \mathrm{Tc}^{\mathrm{r}} \mathrm{Ap}^{\mathrm{r}} \mathrm{Cm}^{\mathrm{r}}$ & Simon et al. (1982) \\
\hline pCI6 & $\begin{array}{l}\text { pSUP202 carrying attP } \\
\text { of phage } \phi \mathrm{U}\end{array}$ & This work \\
\hline pUC18 & $\mathrm{Ap}^{\mathrm{r}}$ lac $Z^{\prime}$ & $\begin{array}{l}\text { Yanisch-Perron et al. } \\
\text { (1985) }\end{array}$ \\
\hline
\end{tabular}

${ }^{*} m b^{+}$, mobilizable by tra gene; $\mathrm{Tc}^{\mathrm{r}}$, tetracycline resistant; $\mathrm{Ap}^{\mathrm{r}}$, ampicillin resistant; $\mathrm{Cm}^{\mathrm{r}}$, chloramphenicol resistant.
Agarose gel electrophoresis. Plasmids from E. coli, total cellular DNAs from Rhizobium and restriction fragments of DNAs were separated on $0.7 \%$ agarose gels. Electrophoresis was performed in TBE-buffer ( 89 mM-Tris base, 2 mm-EDTA, 89 mm-boric acid, pH 8.4) at $50 \mathrm{~V}$ for $14 \mathrm{~h}$ for Rhizobium plasmids and at $100 \mathrm{~V}$ for $90 \mathrm{~min}$ for $E$. coli plasmids and restriction fragments. Agarose gels were stained with ethidium bromide and observed in UV light $(302 \mathrm{~nm})$.

Isolation of DNA fragments from agarose gel. After agarose gel electrophoresis, the stained DNA band of interest was excised, transferred to a small centrifuge tube with a membrane filter (Ultrafree$\mathrm{C} 3$, Millipore), and isolated under the conditions recommended by the manufacturer. Isolated DNA was directly labelled for use as a hybridization probe or cloned into the appropriate cloning sites on plasmid vector pUC18.

Southern hybridization. After agarose gel electrophoresis, DNAs in the gel were denatured with $200 \mathrm{~mm}$-hydrochloric acid followed by $1 \mathrm{M}$ sodium hydroxide. DNAs were then transferred to a Nytran NY13N filter (Shleicher and Schüll) by vacuum blotting. The blotted filters were irradiated with UV light ( $302 \mathrm{~nm}$ ) for $4 \mathrm{~min}$ to bind DNAs strongly to the filters. Plasmid DNA or isolated DNA from the agarose gel were labelled with digoxigenin and used as probes. Hybridization and colorimetric detection were performed according to the manufacturer's instructions (Boehringer Mannheim).

Construction of plasmid $p C 16$. The $6.0 \mathrm{~kb}$ Eco RI fragment of phage $\phi \mathrm{U}$ DNA, which was identified as an attP fragment in this work, was cloned into an EcoRI site of pUC18 and maintained in E. coli LE392. Purified pUC18 carrying the attP fragment and mobilizable $\left(m o b^{+}\right)$ suicide plasmid pSUP202 were digested with EcoRI, ligated with T4 DNA ligase, and introduced into $E$. coli VCS257 by electroporation (Gene Pulser, Bio-Rad). Because the EcoRI site locates within the $\mathrm{Cm}^{\mathrm{r}}$ gene on pSUP202, $\mathrm{Ap}^{\mathrm{r}} \mathrm{Tc}^{\mathrm{r}} \mathrm{Cm}^{\mathrm{s}}$ colonies were selected as transformants and their plasmids were confirmed. Plasmid pSUP202 carrying the attP fragment of phage $\phi \mathrm{U}$ was referred to as plasmid pCI6.

Bacterial matings for transfer of plasmid pCI6 into Rhizobium cells. In advance of mating, plasmid pCI6 was introduced to $E$. coli S17-1. Donor E. coli S17-1 harbouring pCI6 and recipient Rhizobium were grown in LB medium and TY medium for $24 \mathrm{~h}$, respectively. A $100 \mu \mathrm{l}$ sample (ca. $5 \times 10^{7}$ cells) of each culture was centrifuged, and washed twice with sterile distilled water, then $50 \mu \mathrm{l}$ of the mixture was spotted onto sterile filters (HAWP01300, Millipore) on TY agar plates. After overnight incubation at $30^{\circ} \mathrm{C}$, the cells on the filter were washed twice with sterile distilled water and resuspended in $1 \mathrm{ml}$ of sterile distilled water. The conjugated mixture was plated onto minimal medium containing Tc $\left(20 \mu \mathrm{g} \mathrm{ml}^{-1}\right)$ for selection of Rhizobium transconjugants; $4 \mathrm{~d}$ after plating, colonies were counted to estimate the frequency of transconjugant appearance.

Phage sensitivity test and phage induction test. Phage sensitivity and induction with mitomycin $\mathrm{C}$ of phage $\phi \mathrm{U}$ in Rhizobium strains were determined as described previously (Uchiumi et al., 1989).

Nodulation test. Nodulation and nitrogen fixation ability of Rhizobium strains were confirmed on white clover (Trifolium repens $\mathrm{L}$. cultivar Ladino) as described by Higashi et al. (1983).

\section{Results}

\section{Identification of the attP fragment of phage $\phi U D N A$}

If phage $\phi \mathrm{U}$ integrates into the chromosome of $R h i$ zobium at the site of the $6.0 \mathrm{~kb} E c o \mathrm{RI}$ fragment of phage $\phi \mathrm{U}$ DNA, then att $L$ and att $R$ should be detectable among DNA fragments of lysogenic strain $4 \mathrm{~S}(\phi \mathrm{U})$ by Southern hybridization using the EcoRI $6.0 \mathrm{~kb}$ fragment 
EcoRI

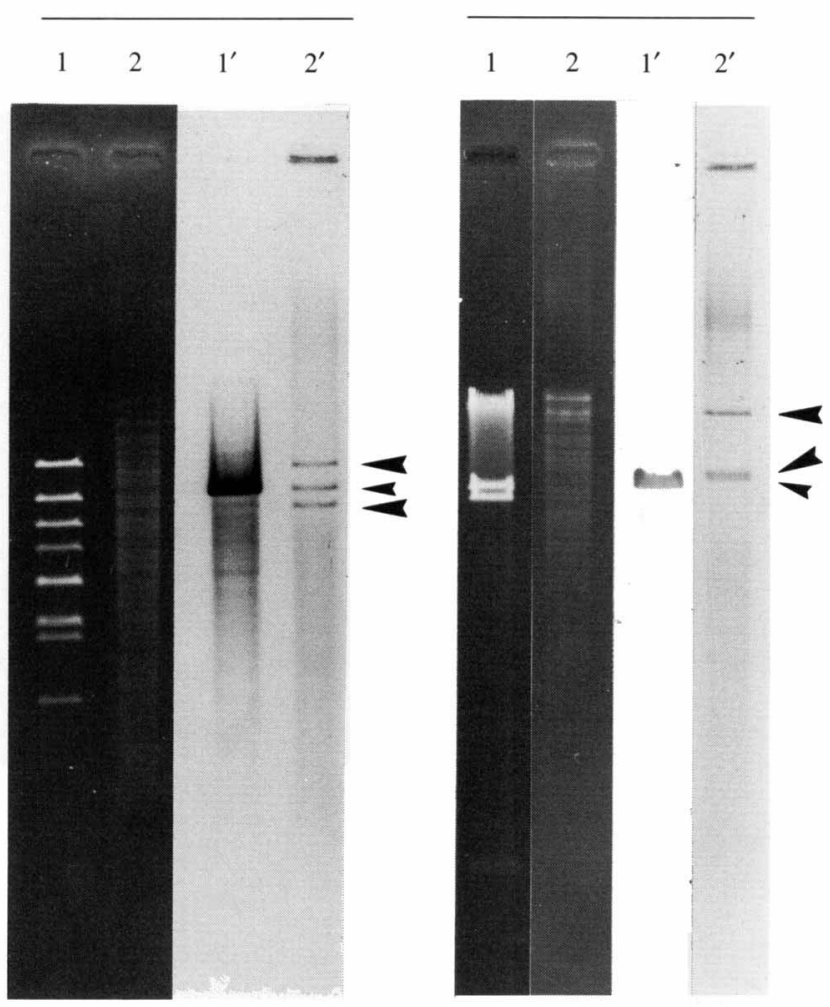

Fig. 1. Southern hybridization for identification of the attP fragment of phage $\phi \mathrm{U}$ DNA. EcoRI-and BamHI-digested DNA from $R$. leguminosarum biovar trifolii strain $4 \mathrm{~S}(\phi \mathrm{U})$ were hybridized with a digoxigenin-labelled $6.0 \mathrm{~kb} E c o$ RI putative attP fragment of phage $\phi \mathrm{U}$ DNA. Lanes 1, phage $\phi \mathrm{U}$ DNA digested with EcoRI and BamHI, respectively; lanes 2, strain $4 \mathrm{~S}(\phi \mathrm{U})$ DNA digested with EcoRI and BamHI, respectively; lanes $1^{\prime}$, phage $\phi \mathrm{U}$ DNA hybridized with putative phage $\phi \mathrm{U}$ att $P$ fragment; lanes $2^{\prime}$, strain $4 \mathrm{~S}(\phi \mathrm{U})$ DNA hybridized with putative phage $\phi \mathrm{U}$ attP fragment. For explanation of bands indicated by large and small arrowheads, see text.

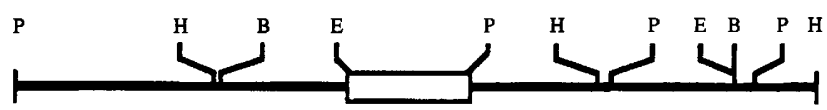

$1 \mathbf{k b}$

Fig. 2. Restriction map of the attP region of phage $\phi \mathrm{U}$ DNA. This map was prepared by summarizing the results of Southern hybridization against restriction fragments of phage $\phi \mathrm{U}$ and the lysogenic Rhizobium strain $4 \mathrm{~S}(\phi \mathrm{U})$ probed with the attP fragment of phage $\phi \mathrm{U}$. The open box is a $2.3 \mathrm{~kb} E c o \mathrm{RI}-P s t \mathrm{I}$ fragment which contains the attP site. B, BamHI; E, EcoRI; H, HindIII; P, PstI.

as a probe. Total cellular DNA was prepared from $R$. leguminosarum biovar trifolii lysogenic strain $4 \mathrm{~S}(\phi \mathrm{U})$, and digested with EcoRI and BamHI. Southern hybridization of fragments of phage $\phi \mathrm{U}$ and lysogenic strain $4 \mathrm{~S}(\phi \mathrm{U})$ DNAs probed with the digoxigenin labelled putative att $P$ fragment ( $6.0 \mathrm{~kb} E c o \mathrm{RI}$ fragment) of phage $\phi \mathrm{U}$ DNA are shown in Fig. 1. Three hybridized bands were detected in fragmented DNA of strain $4 \mathrm{~S}(\phi \mathrm{U})$, whereas only one band was detected in phage $\phi \mathrm{U}$ DNA. This indicates that the $6.0 \mathrm{~kb} E c o \mathrm{RI}$ fragment of phage $\phi \mathrm{U}$ DNA is split in the lysogen. Two fragments which did not exist in phage $\phi \mathrm{U}$ DNA (indicated by large arrowheads in lanes $2^{\prime}$ ) were judged to carry att $L$ and att $R$ in lysogenic strain $4 \mathrm{~S}(\phi \mathrm{U})$. The other fragment (indicated by small arrowheads in lanes $2^{\prime}$ ) was interpreted as the att $P$ fragment itself, derived from vegetative phage $\phi \mathrm{U}$ DNA in strain $4 \mathrm{~S}(\phi \mathrm{U})$ cells, because corresponding fragments could be detected by agarose gel electrophoresis of phage $\phi \mathrm{U}$ DNA (lanes 1). The attP fragment was detected at almost equal intensity to att $L$ and $a t t R$ (lanes $2^{\prime}$ ), contrary to the results reported by Waldman et al. (1986) and Duchrow \& Giffhorn (1987). The DNA isolation procedure employed in this work is suitable for isolation of large plasmid DNA in Rhizobium, and should also favour autonomous replicating phage DNA in the lysogenic strain. When Southern hybridization was performed using other EcoRI fragments of phage $\phi U$ DNA as probes, they hybridized with only one fragment, corresponding to themselves, in lysogenic strain $4 \mathrm{~S}(\phi \mathrm{U})$ (data not shown). These hybridization data support the designation of the $6.0 \mathrm{~kb} E c o \mathrm{RI}$ fragment as the attP fragment of phage $\phi \mathrm{U}$ DNA.

\section{Restriction map of the attP fragment}

Phage $\phi \mathrm{U}$ DNA prepared from phage particles was single- and double-digested with restriction endonucleases BamHI, EcoRI, HindIII and PstI, then hybridized with the $6.0 \mathrm{~kb} E c o \mathrm{RI}$ att $P$ fragment for restriction mapping. Fig. 2 shows the restriction map of an $11.7 \mathrm{~kb}$ Pst $\mathrm{I}-H$ indIII fragment on which the $6.0 \mathrm{~kb}$ EcoRI att $P$ fragment is located. When Southern hybridization was performed against $E c o \mathrm{RI}$ and $B a m \mathrm{HI}$ digests of lysogen $4 \mathrm{~S}(\phi \mathrm{U})$ DNA using a $2 \cdot 3 \mathrm{~kb}$ EcoRI-PstI fragment (indicated as an open box in Fig. 2) as a probe, two fragments of att $L$ and att $R$ were detected (data not shown). This indicates that the integration might occur within the $2.3 \mathrm{~kb}$ Eco RI-PstI fragment.

\section{Transfer of plasmid pCI6 into Rhizobium}

The attP fragment of the $6.0 \mathrm{~kb} E c o$ RI fragment of phage $\phi \mathrm{U}$ DNA was cloned into the EcoRI site of suicide plasmid pSUP202 and referred to as pCI6. E. coli S17-1 transformed with pCI6 was used as a conjugation donor. Plasmid pCI6 encodes tetracycline resistance $\left(\mathrm{Tc}^{\mathrm{r}}\right)$ and ampicillin resistance $\left(\mathrm{Ap}^{\mathrm{r}}\right)$ as selection markers, and carries a $m o b$ gene $\left(m o b^{+}\right)$derived from plasmid RP4. E. coli $\mathrm{S} 17-1$ is able to transfer $m o b^{+}$plasmids such as pCI6 and pSUP202 to other bacterial genera including Rhizobium by trans function of the tra (transfer) gene on its chromosome (Simon et al., 1983).

$R$. leguminosarum biovar trifolii strain $4 \mathrm{~S}$ and its 
(a)

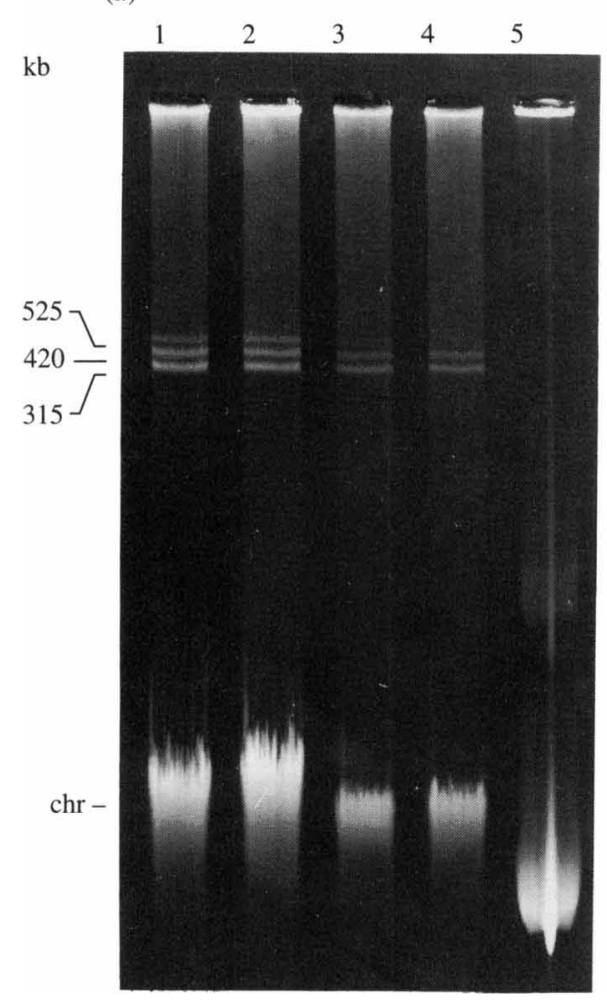

(b)

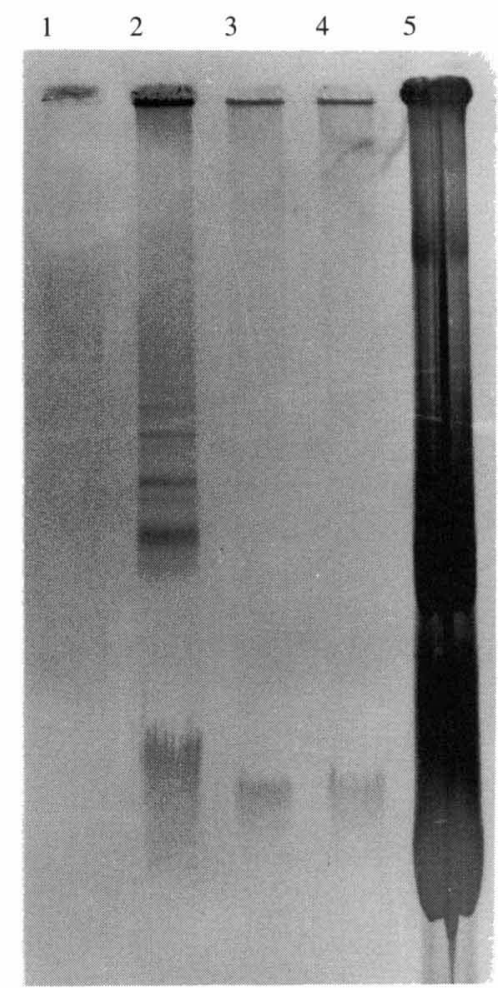

Fig. 3. Agarose gel electrophoresis $(a)$ and Southern hybridization $(b)$ of total cellular DNAs from Rhizobium strains and plasmid pCI6. Digoxigenin-labelled pCI6 was used as a hybridization probe. Lanes 1 , strain $4 \mathrm{~S}$; lanes 2 , strain $4 \mathrm{~S}(\phi \mathrm{U})$; lanes 3 , strain CI101; lanes 4, strain CI301; lanes 5, plasmid pCI6 from E. coli VCS257 harbouring pCI6. chr, Fragmented chromosome DNA.

lysogenic derivative strain $4 \mathrm{~S}(\phi \mathrm{U})$ were mated with $E$. coli S17-1 harbouring pCI6, respectively. Rhizobium transconjugants were selected on minimal agar plates containing tetracycline. Ap ${ }^{\mathrm{r}}$ was not used as a selection marker because strains $4 \mathrm{~S}$ and $4 \mathrm{~S}(\phi \mathrm{U})$ are intrinsically resistant to ampicillin. The frequency of appearance of $\mathrm{Tc}^{r}$ transconjugants was estimated (average of three independent mating experiments). $\mathrm{Tc}^{\mathrm{r}}$ transconjugants appeared at a high frequency of $4.4 \times 10^{-3}$ for strain $4 \mathrm{~S}$ as a recipient and at $2.9 \times 10^{-4}$ for strain $4 \mathrm{~S}(\phi \mathrm{U})$ as a recipient, respectively. No transconjugants were obtained by matings with $E$. coli S17-1 harbouring pSUP202 as a donor. This indicates that pSUP202 could not replicate in Rhizobium. Because pCI6 also could not replicate in Rhizobium, pCI6 was expected to integrate into the chromosome of Rhizobium by site-specific recombination between the attP and $a t t B$ sites.

\section{Characteristics of CI strains}

Phage $\phi \mathrm{U}$ productivity, sensitivity to phage $\phi \mathrm{U}$, and symbiotic phenotypes were investigated in ten transconjugants of the CI100 series (recipient, strain 4S) and ten transconjugants of CI300 series [recipient, strain $4 \mathrm{~S}(\phi \mathrm{U})]$, respectively. All transconjugants maintained nodulation and nitrogen fixation ability on white clover.
Transconjugants of the CI100 series retained the characteristics of the parent strain $4 \mathrm{~S}$, which had no phage $\phi \mathrm{U}$ and was sensitive to phage $\phi \mathrm{U}$ infection. Transconjugants of the $\mathrm{CI} 300$ series lost phage $\phi \mathrm{U}$ productivity and were sensitive to phage $\phi \mathrm{U}$, whereas the parent strain $4 \mathrm{~S}(\phi \mathrm{U})$ had phage $\phi \mathrm{U}$ and was resistant to phage $\phi \mathrm{U}$ infection. This indicates that the CI300 series strains have apparently lost the integrated phage $\phi \mathrm{U}$ present in the parent strain $4 \mathrm{~S}(\phi \mathrm{U})$. Transfer of pCI6 into the lysogenic strain $4 \mathrm{~S}(\phi \mathrm{U})$ may exclude prophage from the chromosome by the integration and exicision mechanism.

Representative transconjugants, strains CI101 and CI301 were used in subsequent experiments.

\section{Confirmation of chromosomal integration of pCI6 in Rhizobium}

To distinguish pCI6 among various possible locations, total cellular DNAs prepared from transconjugants and respective parent strains were analysed by agarose gel electrophoresis and Southern hybridization with the pCI6 probe (Fig. 3). Plasmid pCI6 (lanes 5) was prepared from $E$. coli VCS257 harbouring pCI6 and used as a hybridization probe. All Rhizobium strains have three plasmids, of 525,420 and $315 \mathrm{~kb}$. The $315 \mathrm{~kb}$ plasmid in each strain was identified as the Sym plasmid (Higashi $e t$ 
(a)

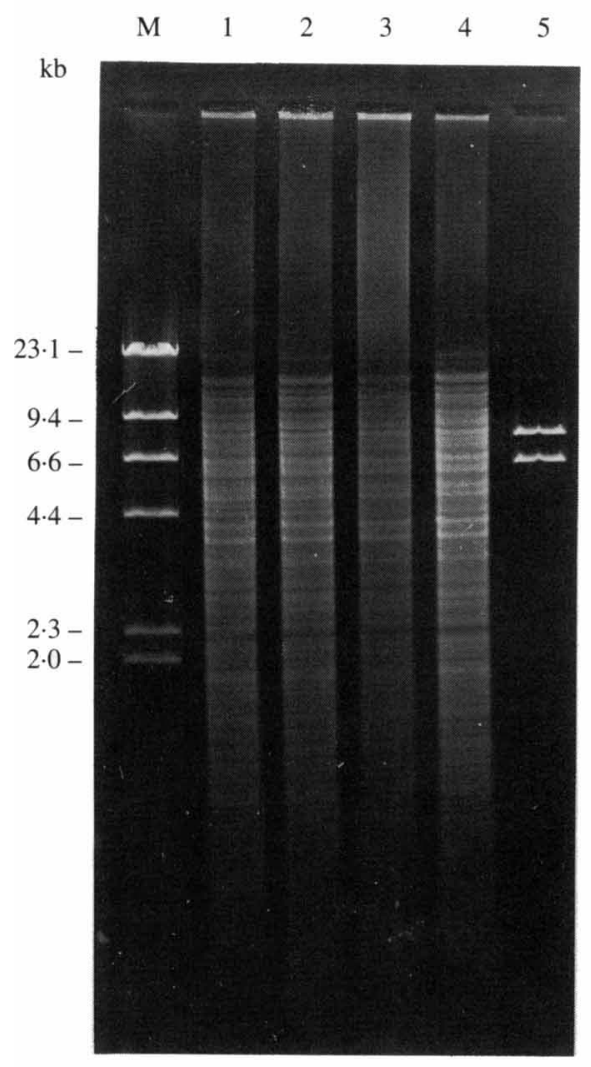

(b)

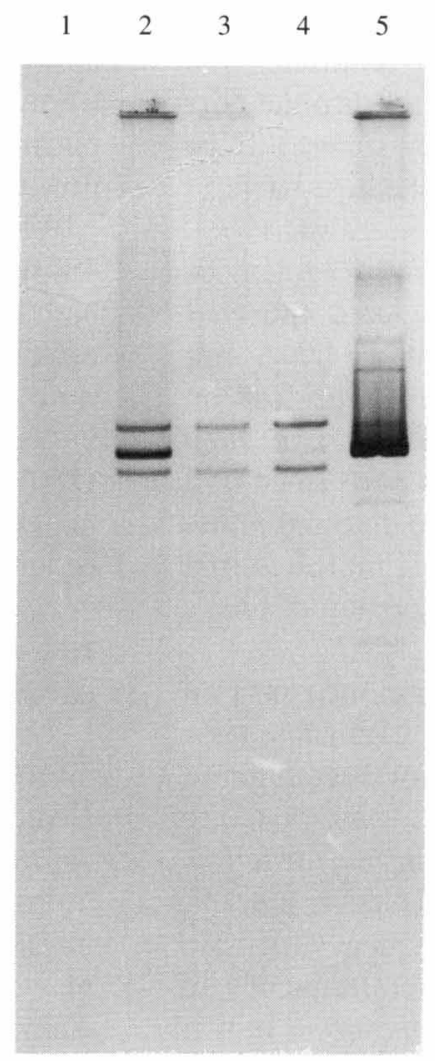

(c)

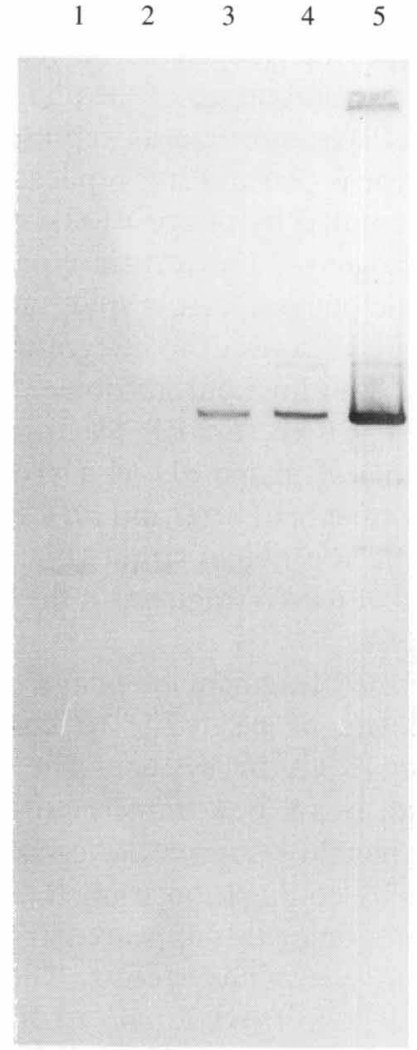

Fig. 4. Agarose gel electrophoresis and Southern hybridization of DNAs from Rhizobium strains probed with the attP fragment and pSUP202. DNAs from Rhizobium strains and plasmid pCl6 were digested with EcoRI and separated on a $0.7 \%$ agarose gel $(a)$. Southern-blotted filters were hybridized with the attP fragment $(b)$ and pSUP202 $(c)$. Lane M, $\lambda$ phage HindIII fragments as molecular mass markers; lanes 1, strain $4 \mathrm{~S}$; lanes 2, strain $4 \mathrm{~S}(\phi \mathrm{U})$; lanes 3, strain CI101; lanes 4, strain CI301; lanes 5, plasmid pCI6.

al., 1983; Uchiumi et al., 1989). No plasmid bands corresponding to pCI6 could be detected in total cellular DNAs from strains CI101 and CI301 (Fig. $3 a, b$, lanes 3 and 4). This indicated that pCI6 did not exist in CI strains as an autonomously replicating plasmid. Besides the fragmented chromosomal DNA, many hybridized bands were detected in strain $4 \mathrm{~S}(\phi \mathrm{U})$ (Fig. $3 b$, lane 2). These were assumed to be vegetative phage $\phi \mathrm{U}$ DNA in strain $4 \mathrm{~S}(\phi \mathrm{U})$ cells. The attP probe hybridized with fragmented chromosomal DNA in strains CI101 and CI301, and did not hybridize with plasmids and chromosomal DNAs from strain 4S (Fig. $3 b$, lanes 1,3 and 4). These data suggest that plasmid pCI6 integrated into the chromosome in strains CI101 and CI301.

To confirm the chromosomal integration of pCI6 and locate its site of integration, total cellular DNAs from Rhizobium strains were digested with EcoRI, and hybridized with the labelled att $P$ fragment and pSUP202 (Fig. 4). Plasmid pCI6 was digested into two fragments of the att $P$ fragment and pSUP202 with EcoRI (Fig. $4 a$, lane 5). Southern blots probed with the att $P$ fragment are shown in Fig. 4(b). Three bands were detected in strain $4 \mathrm{~S}(\phi \mathrm{U})$ DNA (Fig. $4 b$, lane 2). The longest and the shortest bands were identified as att $L$ and attR fragments. The middle band was derived from the attP fragment of vegetative phage $\phi \mathrm{U}$ DNA in cells of strain $4 \mathrm{~S}(\phi \mathrm{U})$. In DNAs from strains $\mathrm{CI} 101$ and $\mathrm{CI} 301$, only two bands corresponding to att $L$ and att $R$ were detected (Fig. $4 b$, lanes 3 and 4 ). A very faint band was detected between the attL and attR fragments of strain CI301 (Fig. $4 b$, lane 4). This band may be a partially digested fragment, because its length was slightly different from that of the attP fragment. No hybridizing band could be detected in DNA from wild-type strain 4S (Fig. $4 b$, lane $1)$.

Southern hybridization was also performed using pSUP202 as a probe (Fig. $4 c$ ). The hybridized band identical to pSUP202 could be detected in both CI101 and CI301 strains. The very faint band of approximately $3.0 \mathrm{~kb}$ in all Rhizobium strains may be an $\mathrm{Ap}^{\mathrm{r}}$ gene which is analogous to that on pSUP202.

These hybridization results support the proposal that plasmid pCI6 integrates entirely into the chromosome of CI strains by integrative site-specific recombination between attP on pCI6 and attB on the Rhizobium chromosome. 


\section{Discussion}

Two types of lysogenization have been reported. One type is the integration of the phage genome into the host bacterial chromosome as represented by phage $\lambda$. The other type is plasmid-like replication in the host bacteria as represented by phage P1 (Ikeda \& Tomizawa, 1968). In a lysogen of the former type, the attP fragment of lysogenic phage DNA is split, generating att $L$ and att $R$ fragments as a result of integrating the phage DNA into the bacterial host chromosome. Southern hybridization using a $6.0 \mathrm{~kb} E c o \mathrm{RI}$ fragment (the putative attP fragment) of phage $\phi \mathrm{U}$ as a probe was performed and two fragments of attL and attR could be detected in the lysogenic Rhizobium strain (Fig. 1). This indicates that the $E c o$ RI $6.0 \mathrm{~kb}$ fragment is the attP fragment of phage $\phi \mathrm{U}$ DNA.

The att $P$ fragment of phage $\phi \mathrm{U}$ was cloned into an EcoRI site of pSUP202 to construct a chromosome integrative vector system. The resultant recombinant plasmid, pCI6, was transferred from $E$. coli $\mathrm{S} 17-1$ into wild-type and lysogenic $R$. leguminosarum biovar trifolii strains by conjugation using $\mathrm{Tc}^{\mathrm{r}}$ as a selection marker. $\mathrm{Tc}^{\mathrm{r}}$ transconjugants appeared at high frequency for both recipient Rhizobium strains. The transfer frequency of plasmid pCI6 from $E$. coli to $R$. leguminosarum biovar trifolii strains was significantly higher than that reported for transfer of the wide host range pKT230 and pKT231 plasmids into $R$. meliloti $\left(10^{-5}\right.$; Donnelly et al., 1987).

By Southern hybridization analyses of transconjugant Rhizobium strains, it was revealed that pCI6 integrates into the bacterial chromosome by site-specific recombination between $a t t P$ on pCI6 and $a t t B$ on the bacterial chromosome. The integration reaction is mediated by the phage-encoded protein integrase (Int) and the IHF (integration host factor) of host bacteria [see Sadowski (1986) for review]. Leong et al. (1986) have reported the 1728 bp DNA sequence encoding the $19 \mathrm{bp}$ attP core sequence and the Int protein. The termination of the Int protein is located only $16 \mathrm{bp}$ upstream of the attP core sequence. If the structure of the attP region and the integration mechanism of phage $\phi \mathrm{U}$ are similar to those for phage $\lambda$, the int gene may be located on the $6.0 \mathrm{~kb}$ $E c o$ RI attP fragment of phage $\phi \mathrm{U}$ DNA. Plasmid pCI6 integrates into the chromosome of $R$. leguminosarum biovar trifolii at a high frequency at the site of phage $\phi \mathrm{U}$ integration. This indicates that the integrase gene on the attP fragment functions efficiently in Rhizobium host cells.

The excisionase gene (xis) which mediates excision of prophage DNA from the chromosome is located near the att $P$ site (Leong et al., 1986). There is a possibility that xis resides on pCI6 and functions in the same way as int. The excision of pCI6 from the chromosome of the transconjugants has not been observed so far when tetracycline is present in the medium. However, it is very important to estimate the frequency of pCl6 excision from the integrated state, when considering the application of pCI6 for accurate analyses on gene expression in Rhizobium.

When pCI6 was introduced into the lysogenic strain $4 \mathrm{~S}(\phi \mathrm{U})$, the resulting transconjugants of $\mathrm{CI} 300$ series had lost immunity against phage $\phi \mathrm{U}$ and ability to produce phage $\phi \mathrm{U}$. These results suggest that phage $\phi \mathrm{U}$ is no longer present in the CI300 series. Transfer of pCI6 into strain $4 \mathrm{~S}(\phi \mathrm{U})$ cells may cause exclusion of prophage DNA from the chromosome of strain $4 \mathrm{~S}(\phi \mathrm{U})$ by the integration and excision mechanism. Plasmid pCI6 will become a useful tool to study the mechanism of integration and excision of lysogenic phage in Rhizobium and also be useful as a chromosome integrative vector, like the vectors reported by Hermesz et al. (1992).

The entire $40 \mathrm{~kb}$ phage $\phi \mathrm{U}$ genome is able to integrate into the Rhizobium host chromosome. Plasmid pCI6 is also expected to integrate large DNA fragments into the Rhizobium chromosome without any deletions. The insertion into pCI6 of the cos site for packaging and a multi-cloning site will make this possible. The application of pCI6 as a chromosome integrative vector for other Rhizobium species should also be investigated.

We would like to thank Dr R. Simon and Professor A. Pühler for providing us with plasmid pSUP202 and E. coli S17-1. We also wish to thank Professor Frank Dazzo for critical reading of the manuscript and helpful comments.

\section{References}

BERINGER, J. E. (1974). R-factor transfer in Rhizobium leguminosarum. Journal of General Microbiology 84, 188-198.

Birnboim, H. C. \& Doly, J. (1979). A rapid alkaline extraction procedure for screening recombinant plasmid DNA. Nucleic Acids Research 7, 1513-1523.

Buchanan-Wollaston, A. V. (1979). Generalized transduction in Rhizobium leguminosarum. Journal of General Microbiology 112, 135-142.

Casse, F., Boucher, C., Julliot, J. S., Michel, H. \& DÉnarié, J. (1979). Identification and characterization of large plasmids in Rhizobium meliloti using agarose gel electrophoresis. Journal of General Microbiology 113, 229-242.

DallmanN, G., Orosz, L. \& SaIN, B. (1979). Restriction mapping of DNA of temperate Rhizobium meliloti phage 16-3: comparison of genetic and physical maps indicates a long, genetically silent chromosomal arm. Molecular and General Genetics 176, 439-448.

DonNelly, D. F., BIRKENhEAD, K. \& O'GARA, F. (1987). Stability of IncQ and IncP-1 vector plasmids in Rhizobium spp. FEMS Microbiology Letters 42, 141-145.

Dorgai, L., Olasz, F., Berényi, M., Dallmann, G., PÁy, A. \& Orosz, L. (1981). Orientation of the genetic and physical map of Rhizobium meliloti temperate phage 16-3. Molecular and General Genetics 182, 321-325.

Dorgai, L., Olasz, F. \& Németh, K. (1986). Lysogenic control of temperate phage 16-3 of Rhizobium meliloti 41 is governed by two distinct regions. Molecular and General Genetics 205, 568-571.

DuChrow, M. \& GifFHORN, F. (1987). Physical map of the Rhodobacter 
sphaeroides bacteriophage $\phi$ RsG1 genome and location of the prophage on the host chromosome. Journal of Bacteriology 169, $4410-4414$.

Finan, T. M., Hartwieg, E., LeMieux, K., Bergman, K., Walker, G. C. \& SigneR, E. R. (1984). General transduction in Rhizobium meliloti. Journal of Bacteriology 159, 120-124.

HATTORI, M., HidaKa, S. \& SAKAKI, Y. (1985). Sequence analysis of a KpnI family member near the $3^{\prime}$ end of human $\beta$-globin gene. Nucleic Acids Research 13, 7813-7827.

Hermesz, E., Olasz, F., Dorgai, L. \& Orosz, L. (1992). Stable incorporation of genetic material into the chromosome of Rhizobium meliloti 41 : construction of an integrative vector system. Gene 119 , 9-15.

Higashi, S. \& ABE, M. (1980). Promotion of infection thread formation by substances from Rhizobium trifolii. Journal of Applied and Environmental Microbiology 39, 297-301.

HIGASHI, S., UCHIUMI, T. \& ABE, M. (1983). Elimination of Rhizobium infectivity by temperature treatment. Journal of General and Applied Microbiology 29, 281-285.

IkeDA, H. \& Tomizawa, J. (1968). Prophage P1, an extrachromosomal replication unit. Cold Spring Harbor Symposia on Quantitative Biology 33, 791.

Keele, B. B., Hamilton, P. B. \& Elkan, G. H. (1969). Glucose catabolism in Rhizobium japonicum. Journal of Bacteriology 97, 1184-1191.

KowalsKI, M. (1967). Transduction in Rhizobium meliloti. Acta Microbiologica Polonica 16, 7-12.

Leong, J. M., Nunes-Dueby, S. E., Oser, A. B., Lesser, C. F., Youderian, P., SusSKIND, M. M. \& LANDY, A. (1986). Structural and regulatory divergence among site-specific recombination genes of lambdoid phage. Journal of Molecular Biology 189, 603-616.
LoNG, S. R. (1989). Rhizobium genetics. Annual Review of Genetics 23, 483-506.

Martin, M. O. \& Long, S. R. (1984). Generalized transduction in Rhizobium meliloti. Journal of Bacteriology 159, 125-129.

SADOWSKI, P. (1986). Site-specific recombinases: changing partners and doing the twist. Journal of Bacteriology 165, 341-347.

Sambrook, J., Fritsch, E. F. \& Maniatis, T. (1989). Molecular Cloning: A Laboratory Manual, 2nd edn. Cold Spring Harbor, NY: Cold Spring Harbor Laboratory.

SHERwOOD, M. T. (1970). Improved synthetic medium for the growth of Rhizobium. Journal of Applied Bacteriology 33, 708-713.

SiK, T., Harwath, J. \& ChatTerJEe, S. (1980). Generalized transduction in Rhizobium meliloti. Molecular and General Genetics 178, 511-516.

Simon, R., Preiher, U. \& Pühler, A. (1982). A broad host range mobilization system for in vivo genetic engineering; transposon mutagenesis Gram-negative bacteria. Biotechnology 1, 784-791.

UCHIUMI, T., ONo, Y., ABE, M. \& Higashi, S. (1989). Phage induction of lysogenic Rhizobium leguminosarum biovar trifolii in both the freeliving and the symbiotic form. Journal of General Microbiology 135, 3133-3141.

Waldman, A. S., Fitzmaurice, W. P. \& Scocca, J. J. (1986). Integration of the bacteriophage HP1cl genome into the Haemophilus influenzae $\mathrm{Rd}$ chromosome in the lysogenic state. Journal of Bacteriology 165, 297-300.

Yamamoto, K., Alberts, B. M., Benzinger, R., Lawhorne, L. \& TREIBER, G. (1970). Rapid bacteriophage sedimentation in the presence of polyethylene glycol and its application to large-scale virus purification. Virology 40, 734-744.

Yanisch-Perron, C., Vieira, J. \& Messing, J. (1985). Improved M13 phage cloning vectors and host strains: Nucleotide sequences of the M13mp18 and pUC19 vectors. Gene 33, 103-119. 